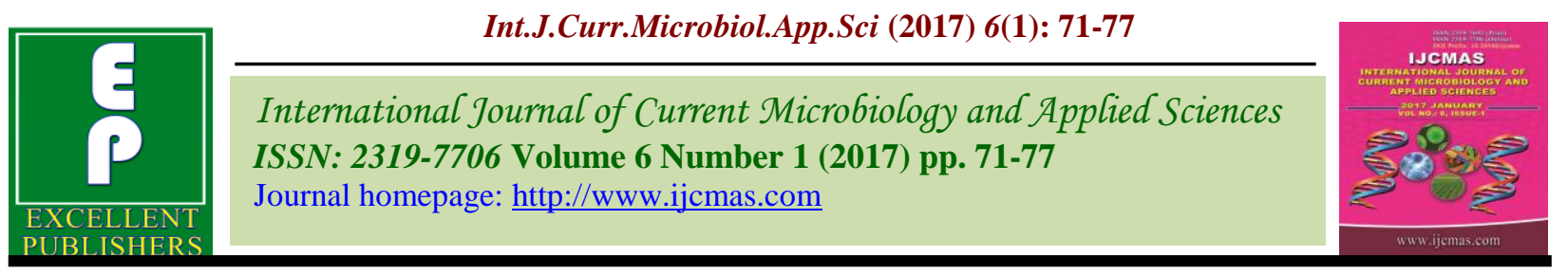

Original Research Article

http://dx.doi.org/10.20546/ijcmas.2017.601.009

\title{
Isolation and Identification of Extra-aquatic, Pathogenic Fungi from the Polluted Water of Munneru River, Telangana, India
}

\author{
D. Saikumari* and Neeti Saxena \\ Mycology and Plant Pathology Lab, Department of Botany, University College For women, \\ Koti, Osmania University, Hyderabad, India \\ *Corresponding author
}

\section{A B S T R A C T}

Keywords

Aquatic fungi,

Pollution, PDA,

Munneru,

Khammam.

Article Info

Accepted:

09 December 2016

Available Online:

10 January 2017
Munneru is a small River and flows through Dornakal Eru, Kaamanchkal and Daanavaayigudem areas of Khammam district, Telangana, India. Munneru is a major water source, the river is so much polluted with the domestic, factories and municipal solid wastes. Surface water samples were collected from three locations of the river. Water samples were cultured immediately. Potato dextrose agar medium was used for culturing. 50 species and 18 genera were isolated. Aspergillus spp, Curvularia spp, Drechslera spp, Fusarium spp, Pencillium spp, Trichoderma spp, were the dominant species isolated from the polluted waters of Munneru River.

\section{Introduction}

Munneru is a left tributary of Krishna River. The river originates in Warangal district, Telangana, India. It flows in the districts of Khammam and Krishna. In Khammam Munneru flows through Dornakal Eru, Kaamanchkal and Daanavayigudem suburbans of this district. The river act as a water source of Khammam district, Telangana, India.

In the world around 300 species are known to be associated with the aquatic habitat (Shearer et al., 2007). Fresh water fungi are a diverse and heterogeneous group comprising many orders viz Hyphomycetes (Cooker, 1923;
Waterhouse, 1942), Oomycetes (Shearer et al., 2007), Chytridiomycetes (Ingold, 1975; Barlocher, 1992), Basidiomycetes (Nakagiri and Ito, 1991). Ascomycetes (Vijayakrishna and Hyde, 2006). Among them Ascomycetes and Hyphomycetes are dominant groups (Vaihya and Deepak paradeshi, 2015). The main role of freshwater Ascomycetes, Basidiomycetes and Mitosporic fungi in fresh water ecosystems are in the degradation of dead organic material (Nizamydeen et al., 2014).

In the present investigation an attempt has been made to study the growth of pathogenic, 
extra-aquatic fungal development in the polluted water of Munneru River.

\section{Materials and Methods}

The water samples were collected in presterilized bottles during the month of June 2016- November 2016 from the 3 locations Viz Dornakal Eru, Kaamanchkal and Daanavayigudem banks of the Munneru River, Khammam district, Telangana, India. Surface water samples were collected to examine the fungal organisms, and taken the samples 2 feet above from the base of the river.

All the samples were plated on Potato dextrose agar medium (Difcomannual, 1969) after isolating them by dilution technique (Pramer and Schmidth, 1966) and stored at room temperature until the colonies were grown. Pure cultures were maintained on the PDA slants and stored at refrigerator.

To identify the mycelium sides were stained with cotton blue in lacto phenol and observed under the electron microscope. The identification of colonies was done by using the hand book of soil fungi (Nagamani and Manoharachary).

\section{Results and Discussion}

50 species and 18 genera were isolated from the river of Munneru. The isolated species were Aspergillus niger, Aspergillus flavus, Aspergillus fumigatus, Aspergillus nidulans, Aspergillus ripens, Aspergillus ustus, Aspergillus ochraceus, Aspergillus terrius, Aspergillus oryzae, Aspergillus awamori, Aspergillus restrictus, Aerobasidium pullulans, Alternaria alternate, Alternaria solani, Curvularia brachyspora, Curvularia lunata, Curvularia geniculate, Cheatomium indicum, Cheatomium globossum, Cheatomium funicola, Cladosporium cladosporioides, Cylindrocladium parvum,
Drechslera tetramera, Drechslera australiensis, Drechslera spicifera, Fusarium moniliformae, Fusarium oxysporum, Fusarium subdlutinans, Fusarium roseum, Macrophomina phaseolina, Mucor globossum, Mucor indicum, Mucor racemosus, Myrothecium roridium, Pencillium chrysogenum, Pencillium rubrum, Pencillium griseofulvum, Periconia byssoides, Pacelomyces spp, Rhizopus stolonifera, Rhizopus nigricans, Rhizopus orizae, Rhizopus arrhizus, Trichoderma koningii, Trichoderma viridae, Trichoderma reesi, Trichoderma harizianum, Verticillium glacum, Verticillium atro-album.

In the bank of Dornakal Eru 16 species were isolated such asAspergillus niger, Aspergillus flavus, Aspergillus fumigatus, Aspergillus nidulans, Aspergillus ripens, Alternaria alternata, Alternaria solani, Fusarium moniliformae, Fusarium oxysporum, Mucor globossum, Mucor indicum, Mucor racemosus, Pencillium chrysogenum, Rhizopus stolonifer, Rhizopus nigricans.

In kaamanchkal 25 species such as Aspergillus niger, Aspergillus flavus, Aspergillus fumigatus, Aspergillus nidulans, Aerobasidium pullulans, Alternaria alternata, Curvularia brachyspora, Curvularia lunata, Curvularia geniculata, Cheatomium indicum, Cheatomium globossum, Cheatomium funicola, Cladosporium cladosporioides, Drechslera australiensis, Drechslera spicifera, Fusarium moniliformae, Fusarium oxysporum, Fusarium roseum, Macrophomina phaseolina, Mucor globossum, Mucor indicum, Mucor racemosus, Pencillium griseofulvum, Periconia byssoides, Paecilomyces spp, Trichoderma viride, Verticillium glacum were isolated.

In Daanavayigudem 36 species Aspergillus niger, Aspergillus flavus, Aspergillus fumigatus, Aspergillus nidulans, Aspergillus 
ripens, Aspergillus ustus, Aspergillus ochraceus, Aspergillus oryzae, Aspergillus awamori, Aspergillus restrictus, Curvularia brachyspora, Curvularia lunata, Curvularia geniculata, Cheatomium indicum, Cheatomium globossum, Cheatomium funicola, Cladosporiumm cladosporioides, Cladosporium variable, Cyclindrocladium parvum, Drechslera spicifera, Fusarium subglutinans, Macrophomina phaseolina, Mucor indicum, Mucor racemosus, Myrothecium roridium, Pencillium chrysogenum, Rhizopus stolonifer, Rhizopus nigricans, Rhizopus orizae, Rhizopus arrhizus, Trichoderma koningii, Trichoderma reesi,Verticillium glacum, Verticillium atraalbum, Trichoderma viridae Were isolated.

In this three locations Daanavayigudem have been recorded more number of fungal organisms than the 2 locations Dornakal Eru and Kaamanchkal.

In the present study the highest numbers of fungi were isolated from the Daanavayigudem area, when compared to the other 2 locations. Aspergillus spp, Curvularia spp, Drechslera spp, Fusarium spp, Pencillium spp, Rhizopus spp, Mucor spp, Trichoderma spp were the dominant species recorded in these 3 locations of Khammam.

Excess levels of nutrients and other chemicals lead to changes in aquatic life (Wesbster and Descals, 1979). Highest fungal organisms were recorded in the Daanavayigudem area due to the presence of domestic sewage, factory chemicals and dumped municipalsolid wastes, which are into the River. These nutrients act as catalysts and enhance the growth of the pathogenic organisms in the aquatic environment (Umesh et al., 2012). The fungal populationincreases with the increase of pollution (Sharada Vaidhya and Deepak Paradeshi, 2015; Somashekhar et al., 1982; Bhupendra singh et al., 2014). Hence Daanavayigudem is considered as a highly polluted region than the Dornkal Eru and Kaamanchkal.

Table.1 The table showing the fungal organisms which were isolated from the 3 locations of Munneru River

\begin{tabular}{|c|c|c|c|c|c|}
\hline S. No & Fungus name & $\begin{array}{c}\text { Dornakal } \\
\text { Eru }\end{array}$ & Kaamanchkal & Daanavayigudem & $\begin{array}{c}\text { Total } \\
\text { species }\end{array}$ \\
\hline 1. & Aspergillus niger & + & + & + & + \\
\hline 2. & Aspergillus flavus & + & + & + & + \\
\hline 3. & $\begin{array}{l}\text { Aspergillus } \\
\text { fumigatus }\end{array}$ & + & + & + & + \\
\hline 4. & $\begin{array}{l}\text { Aspergillus } \\
\text { nidulans }\end{array}$ & + & + & + & + \\
\hline 5. & $\begin{array}{l}\text { Aspergillus } \\
\text { ripens }\end{array}$ & + & & + & + \\
\hline 6. & Aspergillus ustus & + & & + & + \\
\hline 7. & $\begin{array}{l}\text { Aspergillus } \\
\text { ochraceus }\end{array}$ & & & + & + \\
\hline 8. & $\begin{array}{l}\text { Aspergillus } \\
\text { terries }\end{array}$ & & & & + \\
\hline 9. & $\begin{array}{l}\text { Aspergillus } \\
\text { oryzae }\end{array}$ & & & + & + \\
\hline
\end{tabular}




\begin{tabular}{|c|c|c|c|c|c|}
\hline 10. & $\begin{array}{l}\text { Aspergillus } \\
\text { awamori }\end{array}$ & & & + & + \\
\hline 11. & $\begin{array}{l}\text { Aspergillus } \\
\text { restrictus }\end{array}$ & & & 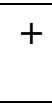 & + \\
\hline 12. & \begin{tabular}{|l|}
$\begin{array}{l}\text { Aerobasidium } \\
\text { pullulans }\end{array}$ \\
\end{tabular} & & + & & + \\
\hline 13. & $\begin{array}{l}\text { Alternaria } \\
\text { alternate }\end{array}$ & + & + & & + \\
\hline 14. & Alternaria solani & + & 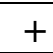 & & + \\
\hline 15. & \begin{tabular}{|l|} 
Curvularia \\
brachyspora
\end{tabular} & & & + & + \\
\hline 16. & $\begin{array}{l}\text { Curvularia } \\
\text { lunata }\end{array}$ & & + & + & + \\
\hline 17. & $\begin{array}{l}\text { Curvularia } \\
\text { geniculate }\end{array}$ & & & + & + \\
\hline 18. & $\begin{array}{l}\text { Cheatomium } \\
\text { indicum }\end{array}$ & & + & + & + \\
\hline $\begin{array}{ll}19 . \\
\end{array}$ & \begin{tabular}{|l|}
$\begin{array}{l}\text { Cheatomium } \\
\text { globossum }\end{array}$ \\
\end{tabular} & & + & + & + \\
\hline 20. & $\begin{array}{l}\text { Cheatomium } \\
\text { finicola }\end{array}$ & & & + & + \\
\hline 21. & $\begin{array}{l}\text { Cladosporium } \\
\text { cladosporioides }\end{array}$ & & + & + & + \\
\hline 22. & \begin{tabular}{|l|}
$\begin{array}{l}\text { Cladosporium } \\
\text { variable }\end{array}$ \\
\end{tabular} & & & + & + \\
\hline 23. & $\begin{array}{l}\text { Cyclindrocladium } \\
\text { parvum }\end{array}$ & & & + & + \\
\hline 24. & $\begin{array}{l}\text { Drechslera } \\
\text { tetramera }\end{array}$ & & & + & + \\
\hline 25. & \begin{tabular}{|l|} 
Drechslera \\
australiensis
\end{tabular} & & + & & + \\
\hline 26. & \begin{tabular}{|l}
$\begin{array}{l}\text { Drechslera } \\
\text { spicifera }\end{array}$ \\
\end{tabular} & & + & + & + \\
\hline 27. & \begin{tabular}{|l|} 
Fusarium \\
moniliformae
\end{tabular} & + & + & & + \\
\hline 28. & $\begin{array}{l}\text { Fusarium } \\
\text { oxysporum }\end{array}$ & + & + & & + \\
\hline 29. & \begin{tabular}{|l|} 
Fusarium \\
subglutinans
\end{tabular} & & & + & + \\
\hline 30. & Fusarium roseum & & + & & + \\
\hline 31. & $\begin{array}{l}\text { Macrophomina } \\
\text { phaseolina }\end{array}$ & & + & + & + \\
\hline 32. & Mucor globossum & + & + & & + \\
\hline 33. & Mucor indicum & + & + & + & + \\
\hline 34. & Mucor racemosus & + & + & + & + \\
\hline
\end{tabular}




\begin{tabular}{|c|c|c|c|c|c|}
\hline 35. & \begin{tabular}{|l|}
$\begin{array}{l}\text { Myrothecium } \\
\text { roridium }\end{array}$ \\
\end{tabular} & & & + & + \\
\hline 36. & \begin{tabular}{|l|} 
Pencillium \\
chrysogenum
\end{tabular} & + & & + & + \\
\hline 37. & $\begin{array}{l}\text { Pencillium } \\
\text { rubrum }\end{array}$ & & & + & + \\
\hline 38. & \begin{tabular}{|l|} 
Pencillium \\
griseofulvum
\end{tabular} & & + & & + \\
\hline 39. & $\begin{array}{l}\text { Periconia } \\
\text { byssoides }\end{array}$ & & + & & + \\
\hline 40. & \begin{tabular}{|l|}
$\begin{array}{l}\text { Paecilomyces } \\
\text { varioti }\end{array}$ \\
\end{tabular} & & + & & + \\
\hline 41. & \begin{tabular}{|l|} 
Rhizopus \\
stolonifera
\end{tabular} & + & & + & 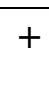 \\
\hline 42. & \begin{tabular}{|l|} 
Rhizopus \\
nigricans
\end{tabular} & + & & + & + \\
\hline 43. & Rhizopus orizae & & & + & + \\
\hline 44. & \begin{tabular}{|l} 
Rhizopus \\
arrhizus
\end{tabular} & & & + & + \\
\hline 45. & $\begin{array}{l}\text { Trichoderma } \\
\text { koningii }\end{array}$ & & & + & + \\
\hline 46. & $\begin{array}{l}\text { Trichoderma } \\
\text { viridae }\end{array}$ & & + & + & + \\
\hline 47. & $\begin{array}{l}\text { Trichoderma } \\
\text { reesi }\end{array}$ & & & + & + \\
\hline 48. & $\begin{array}{l}\text { Trichoderma } \\
\text { harizianum }\end{array}$ & & & + & + \\
\hline 49. & \begin{tabular}{|l|}
$\begin{array}{l}\text { Verticillium } \\
\text { glacum }\end{array}$ \\
\end{tabular} & & + & + & + \\
\hline 50 & $\begin{array}{l}\text { Verticililium } \\
\text { atro-album }\end{array}$ & & & + & + \\
\hline
\end{tabular}

Fig. The figures 1, 2, 3, 4, 5, 6, 7, 8, 9 were showing the fungal organisms which were isolated from the three locations of the Munneru River

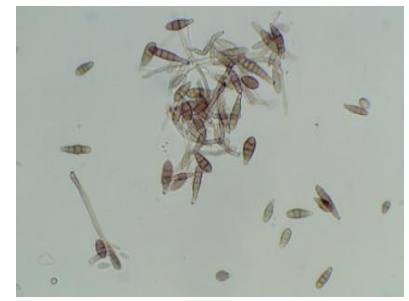

Alternaria alternate

(1)

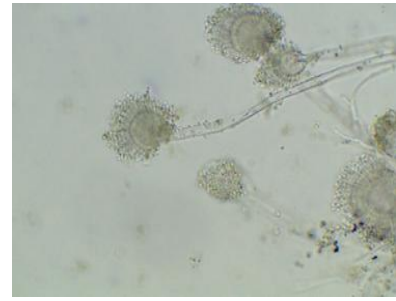

Aspergillus flavus

(2)

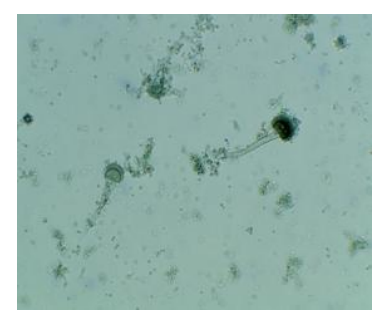

Aspergillus fumigatus

(3) 


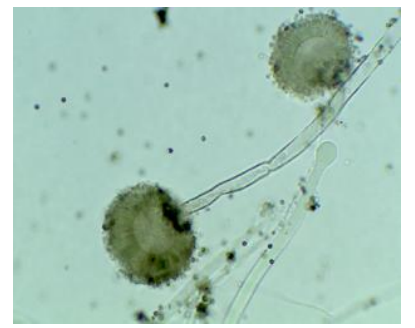

Aspergillus niger

(4)

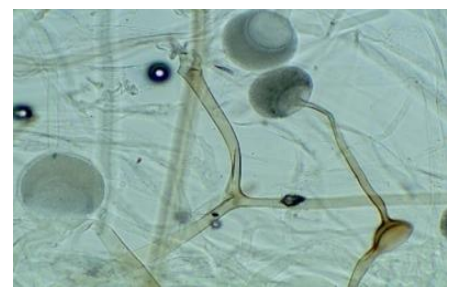

Mucor globossum

(7)

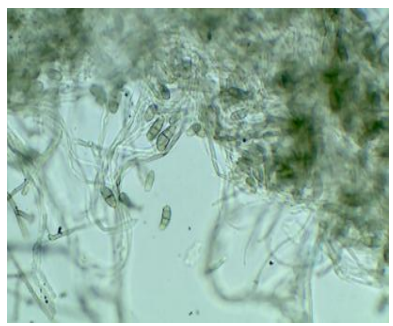

Curvularia luna

(5)

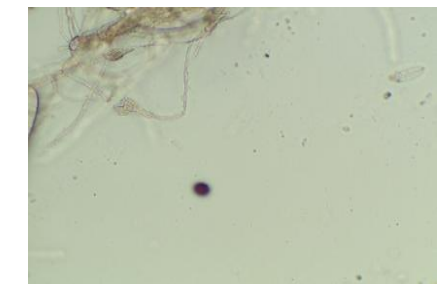

Penicillium chrysogenum

(8)

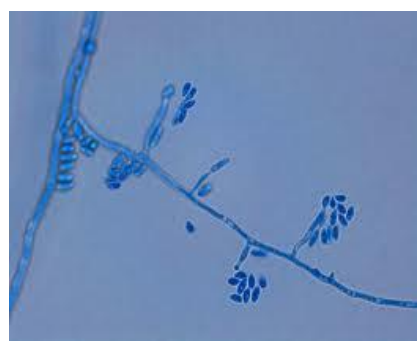

Fusarium oxysporum

(6)

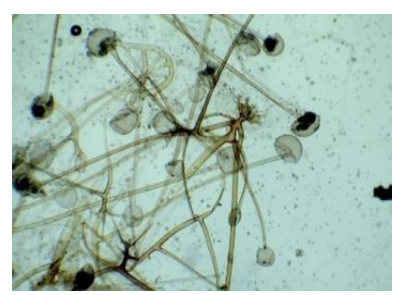

Rhizopus spp

(9)
Minimum number of extra-aquatic and pathogenic fungal members were isolated from the Kaamanchkal area, this area contain normal range of pollution had recorded than Dornakal Eru and Daanavayigudem. Due to the domestic sewage, polluted water and other wastes have been mixed into the bank of kaamanchkal. Less number of fungal members was recorded in Dornakal Eru when compared to the other two areas Kaamanchkal and Daanavayigudem. Usually people use this water for domestic purposes and Agriculture.

Heterotrophic fungal organisms are usually present in nature of the aquatic environment (Goh et al., 2003). Aquatic fungi contribute to the energy flow and productivity of ecosystem by their active role in the utilization and bio deterioration of organic materials (Khuble, 2001). These fungi also possess the ability to parasitize aquatic plants and animals including fishes under certain condition (Cooke, 1977).

In conclusion all the 3 places of Munneru River in Khammam district, Telangana, India, maximum frequency of fungi Aspergillus spp, Curvularia spp, Drechslera spp, Fusarium spp, Pencillium spp, Rhizopus spp, Mucor spp, Trichoderma spp were recorded from the Daanavaayigudem, it was severely polluted area when compared to the other other two banks of Dornakal Eru and Kaamanchkal. Which leads health hazards to the plants and animals.

\section{Acknowledgement}

I sincerely thank UGC for providing NONNET fellowship through the Department of Botany, University College of Science, Osmania University, Hyderabad, and Telangana, India.

\section{References}

Barlocher, F. 1992. (ed). The Ecology of aquatic hyphomycetes. Springer, Berlin, ISBN 3540544003.

Bhupendra Kumar Singh, Saurabh singh, Vandana Srivasthava and D.N. Shukla. 2014. Diversity of Aquatic fungi in three Bank of Ganga river in Varanasi district of Uttar Pradesh.

Cooker, W.C. 1923. The saprolegniaceae with notes on other water molds -Univ. of. 
North Carolina Press: Chapel Hill; Nork Carolina., 201pp; 63pl.

Cooke, W.B. 1997. Fungi in streams, lakes, adjacent, soil and sewage treatment systems in the Flathead. River basin, Montana, Northwest. Sci, 51: 172-182.

Difco Manual, 1969. Difco manual of dehydrated culture media and reagents of microbiological and clinical laboratory procedure, $9^{\text {th }}$ edn, Difco Laboratories, Detroit, Michigun.Pp.32, 64: 243-244.

Goh, T.K., K.M. Clement and C.K.M. Tsui, 2003. Key to Common Dematiaceous Hyphomycetes from Freshwater .In: freshwater Mycology, Tsui, C. K. M. and K. D. Hyde (Ed. Fungal biodiversity Press, Honkong, USA, ISBN-B: 9789628676538, PP; 325-343.

Ingold, C.T. 1975. An illustrated guide to aquatic and waterborne hypomycetes (Fungi imperfecti) with notes on their biology.

Khuble, R.D. 2001. A Mannual of Aquatic fungi (Chytridiomycetes and Oomycetes. $1^{\text {st }}$. Edn, Daya Publishing House, Delhi, India, ISBN. 81-7035-222-3, Pages: 255.

Nakagiri, A., and Ito, T. 1991. Basidiocarp development of the Cyphelloid gasteroid aquatic basidiomycetes Halocyphina villosa and Limnoperdon incarnatum. Canadian J. Bot., 69: 2320-2327.

Nagamani, A., Kunwar, I., Manoharachary K. 2006. Handbook of soil fungi. IK. International Pvt. Ltd.

Nizamydeen, N., Santhiya,T., Ambika, R., sengottaiah, N. 2014. Diversity of aquatic fungi in the Coastal region of
Cauvery River. Adv. Sci. Res., 5(2): 5558.

Pramer, D., Schmidt, E.L. 1996. Experimental soil microbiology. Burges Purges publishing Co, Minnepolis, Minnesota.Pp.106.

Somashekar, R.K., S.N. Rama swamy and Govindappa, D. Arekal. 1982. On the extra Aquatic Fungi from Polluted and unpolluted water of River kapila, Karnata.

Shearer, C., Descals, E., Kohlmeyer, B., Kohlmeyer, J., Marvanova, L., Padgett, D., et al. 2007. Fungal biodiversity Conserv., 16(1): 49-67. doi: 10.1007/S 10531-006-9120z.

Sharada vaidhya and Deepak Paradeshi. 2015. Biodiversity of fungi from soil and water samples from waldhuni River.

Umesh, B., et al. 2012. incidence of Postharvest disease and air borne fungal spores in a vegetable market. Acta Bot. Croat, 71(1): 147-157.

Vijaya Krishna, D., Hyde, K.D. 2006. Inter and intra stream variation of lignicolous fresh water fungi in tropical Australia. Fungal diverse, 21: 203-224.

Waterhouse, G.M. 1942. Some water moulds of the Hogsmill river Collected from 1937to 1939. Trans. Br. Myc. Soc., 25: 315-325.

Webster, J. and E. Descals, 1979. The Telomorphs of waterborne Hyphomycetes from Freshwater, In: The whole Fungus, Kendrick, B(Ed) National museums of Canada and Kananaskis foundation, Ottawa, Canada, ISBN- 13: 978066000463, PP: 419-451.

\section{How to cite this article:}

Saikumari, D., and Neeti Saxena. 2017. Isolation and Identification of Extra-aquatic, Pathogenic Fungi from the Polluted Water of Munneru River, Telangana, India. Int.J.Curr.Microbiol.App.Sci. 6(1): 71-77. doi: http://dx.doi.org/10.20546/ijcmas.2017.601.009 